\title{
Counterpoints, critiques, dialogues
}

A challenge for the field of contemporary civilisational analysis is to rethink heterogeneity, plurality and differentiation in terms of porosity. Interaction between permeable civilisations on different scales and across different dimensions invigorates heterogeneity. If anything, civilisational analysis has yet to benefit from efforts to unearth regular patterns of interaction and gauge the results from long-term rhythms of engagement on the endogenous dynamics of civilisations. The relational model proves to be the most advanced to date in respect of these goals, but it can be pushed further. Before taking steps towards a model of inter-civilisational engagement in Chapter 4 and Part II, I reflect, in this chapter, on competing paradigms. What can they offer in terms of the gaps identified towards the end of the previous chapter, or indeed any others? The three competitors in question are globalisation analysis, Marxism and post-colonial sociology. How they can be situated in relation to contemporary civilisational analysis is the work of this chapter.

The method here is to find productive dissensus between paradigms. A precondition of method is description of the main concept. Paradigms are bodies of thought that are coherent and plausible enough to attract supporters in a general contest of ideas and values. The questions they pose must be sufficiently compelling - and yet also insufficiently resolved - to suggest constructive directions for ongoing research. Moreover, competing paradigms will pose arguments to one another, but also exhibit dissonance. They will 'speak' past each other, as well as to each other. The critiques and counterpoints are treated here from the point of view of paradigmatic dissonance, as well as from the point of view of common spaces between paradigms. In urging an elaboration of common ground between civilisational analysis and international relations, Jackson argues instructively that the lack of agreement paves the way for an agonistic strategy of carving new scholarly terrain out of dissensus. Jackson goes on to argue that by 'working in media res, intervening into an already ongoing set of contentious conversations and exploring a novel combination of commitments', it becomes possible to productively share a dialogue (Jackson, 2010: 179). Applying Jackson's advice on 
the dissensus between civilisational analysis and the three paradigms of globalisation analysis, Marxism and post-colonial sociology, this chapter spells out points of actual or possible dialogue.

In the opening section, critical counterpoints from the globalisation paradigm are foregrounded. It is common for accounts of globalisation to emphasise the novelty of the emergence of the global plane. In civilisational analysis, this is regarded as a species of presentism that ignores longer historical trajectories and complex historical processes. However, there are exceptions. The multidimensional accounts of the emergence of globality by Roland Robertson and Goran Therborn address the criticisms of globalisation analysis. Robertson does so as an interlocutor with civilisational analysis; Therborn's perspective is contrapuntal both exercise a historical sensibility. Common ground exists where the problematics of world region and regionalisation come into focus. By contrast, Marxism is largely silent on the chief problematics that concern civilisational analysis. At the same time, in stressing the rupture of capitalism with past social formations, Marxist critiques highlight a whole area that civilisational analysis has neglected. Three perspectives are compatible with an understanding of capitalism and civilisations as coextensive modern imaginaries: one interpretation of Marx, Antonio Gramsci's Marxism and Robert W. Cox's neo-Gramscian civilisational analysis. The sharpest critiques of civilisational analysis come from post-colonial sociology, which takes aim at the reproduction of essentialism that post-colonial sociologists perceive in comparative studies of civilisations. Furthermore, postcolonial sociologists are explicitly critical of the comparative sociology of multiple modernities on the grounds that it fails to meets its own stated objective of going beyond Eurocentrism. Their critiques home in on how comparative sociologists have retained an unreconstructed notion of modernity incapable of reflecting the breadth of historical experiences of colonialism. Between the two fields there are significant differences over how culture is conceived, what politics should inform analysis and how the character of modernity has been construed. Much of the overt critique comes from post-colonial sociology, but there are rejoinders in civilisational analysis on these points that open up unexplored common ground.

There are key arguments in all three paradigms to take into a conception of inter-civilisational engagement. Robertson and Therborn make the case for longer histories of contemporary configurations or long 'waves' of globalising impulses. Furthermore, civilisations interact with the global plane to constrain processes of homogenisation or de-localisation. The perspectives in Marxism I single out suggest that capitalism's early modernity was more important than has been previously accepted. The coalescence of an imaginary of money and the creation of cultures disposed to accumulation were developments related to 
the growing engagement of civilisations from the sixteenth century onwards as transatlantic colonialism linked the Western hemisphere to civilisations across Eurasia. Extending into later centuries and the outgrowth of Europe's empires, the interaction of civilisations with capitalism produced varieties of capitalist figuration of polity and economy. Finally, post-colonial sociologists argue for the 'connected histories' methodology as a means to overcome the analytical flaws of civilisational analysis and the paradigm of multiple modernities. Connected histories can serve post-colonial critique and the disclosure of historical and current-day hierarchies of power. When partnered with other relational versions of history, the methodology of connected histories can be harnessed to explore the linkages of civilisations also, both in contexts of colonial power and prior to the onset of modern colonial empires. Each of the counterpoints has contributions to make to a reconstructed version of civilisational analysis where problematics can be discerned around which common agonistic debate does, or could, occur.

\section{Globalisation}

The globalisation paradigm has developed coextensively with contemporary civilisational analysis. Though the two paradigms overlap, they also compete with each other as modes of explanation (Inglis, 2010). At first sight, the relationship between the two is a contest between, on one hand, theses on new global forms growing out of higher levels of inter-dependence and, on the other hand, presentation of evidence of countervailing impulses of diversity and re-diversification. Furthermore, globalisation theorists privilege the trans-national mobility of power. When civilisational analysts examine power, they view it as grounded in civilisational contexts where it is shaped by cultural factors. There is also a standoff over questions of continuity and discontinuity (Inglis, 2010: 137-41).

Contemporary civilisational analysis takes its place in a spectrum of responses to globalisation theory. There are a number of criticisms levelled at the globalisation paradigm. The most far-reaching contributions from sociology and anthropology are sharply critical of the worst neo-liberal 'globalony' about the forces of uniformity operating on the world plane. In addition, exponents of the global age thesis stand accused of extending the one-dimensional arguments of modernisation theory by proposing theses of the homogenisation of cultures, economies and governance (for example, see Albrow, 1996). Other criticisms haunt suggestions of over-determining processes of globalisation. Persuasive arguments are backed by evidence that nation-states are not in irreversible decline and continue to vigorously entrench capacities. But perhaps the most serious 
criticism concerns key problematics and the scope of analysis. Many in sociology and amongst social anthropologists caution against the presentism of globalisation theses. Their general views intersect one of the more prominent criticisms of globalisation theory coming from civilisational analysis: that there is a lack of proper perspective on the significance of long historical trajectories (see Tiryakian, 2014). Any serious attempt to extend the historical scope of waves of globalisation ought to begin with the epoch suggested in the early modernities literature. Furthermore, the outgrowth of connections associated with the expansion of modern empires, colonialism and the trans-nationalisation of economic power is a problematic that should be central to understanding early waves of globalisation from the fifteenth century onwards. A global optic of the sixteenth and seventeenth centuries cannot adequately leave out increased density of connections and networks of engagement in several world zones. On the whole, occlusion of early modernity in the globalisation paradigm makes it hard to avoid the conclusion that too much of the argumentation is extrapolated from the sediment of European experience (Connell, 2007).

The best thinkers amongst the scholars of globality seem aware of such problems. While also locating themselves at odds with a number of assumptions of civilisational analysis, Robertson and Therborn develop more complex multidimensional models of globality. To begin with, although Robertson's sociology originated in the Parsonian modernisation paradigm, he developed a multidimensional model of globalisation, partly in dialogue with civilisational analysis in the 1990s. Robertson's thinking formed against the backdrop of Elias's and Gong's notions of the civilising process and over the course of a longer exchange with Vytautos Kavolis (1992: 3). It is in dialogue with Kavolis about universalism and the particularity of civilisational bases that Robertson clarifies the meeting point between globalisation as a process and the civilisational paradigm as an analytic. Robertson's reply to Kavolis is formative for his own concept of international society and therefore globalism. Civilisations have not been erased. Rather, the multiplicity of civilisations is a prelude to globalisation and a consequence of it. His notion of globalisation can be distinguished from more simplistic accounts by the conceptual depth and multidimensional character of its analytic. Globalisation for Robertson is an ideal type of a 'global field' (1992: 25-7). Aside from structural logics of time-space compression, Robertson recognises the crystallisation of 'extensive awareness of the world as a whole' as a long-term outcome of coalescing global culture (1992: 78). The global field includes the world system, national societies, humanity and selves. In construing globalisation through a Parsonian lens Robertson puts culture forward as an abstract order. However, culture encompasses and interacts with economic and political processes rather than existing alongside them. In other words, multidimensional processes are 
presupposed from the outset. Robertson sets the scene by analysing global cultural, religious, cognitive and material dynamics of power at a trans-national and trans-civilisational level well above national societies. Different dimensions of power are not reproduced in a static pattern of inter-dependency, but are highly changeable (Spohn, 2014: 134-5). This conceptual distinction sets Robertson at a distance from his earlier Parsonian sociology.

In examining the interaction of multidimensional processes in economy, culture and politics, Robertson consciously notes the historical dynamics of forces of capitalism and imperialism, which, as he sees it, have been thoroughly researched (1992: 28-9). Robertson's assumption is too hasty. While there have been notable gains in historical scholarship, the theoretical implications are not exhausted. Modern colonialism and capitalism remained under-examined problematics in contemporary civilisational analysis and there is still work to do in theorising power in both domains. In this respect, Robertson's ideal type of the global field has the virtue of a more explicit focus on power and culture. However, his presumption that the historical sociology of capitalism is finished work - or 'well-trodden ground' (1992: 29) - blocked further development.

In respect of culture and power there is a fruitful tension between Robertson's sociology of globalisation and contemporary civilisational analysis. Robertson's vision of the world has phenomenological cadences that open up common ground with civilisational analysis. Civilisations, for Robertson, develop internal images of a world order. Globalisation solicits civilisations 'to be increasingly explicit about what might be called their global callings (their unique geo-cultural or geo-moral contributions to world history)' (1992: 130). The cultivation of civilisational identities by the impulses of globalisation is evident in explicit debates about involvement in the global world. Involvement implies interaction with the world and a relational side to the institution of civilisations. Robertson's main proposition goes in a different direction. Globality, if it is to be meaningful, refers to the outgrowth of worldly consciousness. There is a variety of civilisational responses to the growth of worldly consciousness. In turn, world consciousness sustains the plurality of civilisations. If growth of world consciousness and awareness of 'global involvement' (1992: 132) is one of the strong theses of globalisation, then it must be countered, with Delanty in this instance, that the translation and translatability of whole-world cognitive consciousness is highly complex (Delanty, 2003: 451-2). There is a more forceful diversification of worldly articulations than Robertson allows for. Globality as consciousness looks more like a shifting terrain of different projects of globalisation that continue to imbue places with special meaning. Europe, the United States and Japan are three large projects with which to begin (Inglis, 2010). Robertson is not unaware of this, as evidenced in his elaboration of Japanese globality (Robertson, 
1992: 85-96). But the world appears, in the final instance, a received singular order for him, not one made in coexistence with others as the term 'project' might suggest. The image of the singular world order falls short of the complexities of a longer historical trajectory.

Those complexities are the centrepiece of Goran Therborn's treatment of the problematic of world order. He advances a distinctly historical, multi-variable and pluralist account of globalisation and modernity. This account does not really locate him in the camp of globalisation studies, or that of civilisational analysis, but combines findings of both. The world has been through six waves of globalisation and pathways to modernity that cut across historical civilisations (Therborn, 2011). Two definitions matter in his version of globalisation: civilisation and the idea of 'waves'. To begin with, he defines civilisation as old cultural formations with a very long-term impact on global history. The impact is threefold. First, alongside diffusion of the world religions, cosmologies with a differentiated conception of the sacred spread in the first millennium CE (and not the Axial Age). Second, civilisations institute a canon of works in 'classical' form (for literary civilisations) or mythology (for oral ones). Third, civilisations create sets of social, material and economic practices in shaping environments that produce economic trajectories. Five civilisations laid down the ancient bedrock of the waves of globalisation: the Indic, Sinic, European, West Asian and sub-Saharan. 'Waves' refers to processes of intensification and extension of social processes that have lasting legacies. They can be macro-regional and planetary. But the important point is that waves of globalisation overlap and impact on all dimensions of social, economic, political and cultural life. Over time, and with each wave, more and more of the world is incorporated into common dynamics.

The first wave is synonymous with the Axial Age. In the second wave (15001600), Europe's early modern empires conquered and colonised the Western hemisphere. Indigenous peoples suffered colonial occupation as genocidal conquest and millions of Africans suffered it as the catastrophic slave trade. War and world power were internationalised in the third wave (1750-1815), with Britain emerging as the premier European force at the expense of France. High Imperialism and competition amongst Europe's imperial powers were in the forefront of trends in the fourth wave (1830-1918). Europe overtook Asia as the core macro-region of the world economy for the first time since the height of the Roman Empire. The fourth wave ended with the formation of world organisations like the International Labour Organization and the League of Nations. The fifth wave (1919-89) introduced world politics, the onset of the Cold War and the worldwide revolt against colonialism. Globalisation came into its own in the sixth and final phase from 1990 onwards and entered into popular consciousness. Finance and financialisation emerged as forces of globalisation par excellence. 
Time-space compression altered communication, media, finance, investment, trade and governance, and set the parameters of how the politics of opposition to neo-liberalism and global inequalities would take shape.

The last two waves are the ones normally known as globalisation. More historically minded perspectives begin with the fourth or even third wave. Therborn fixes longer historical phases as reference points and thereby treats older sources of globalisation. He treats force, domination and power as part of the same problematic and process; that is, as a wave of globalisation. These factors are fundamental to globalisation, just as the growth of commerce and migration are. All these dimensions of the waves of globalisation involve interaction between civilisations, sparking a spectrum of conflicts, encounters and connections. In this respect civilisations are seen by Therborn as crucial to globalisation. However, in casting civilisations as the sediments of history and the bedrock of globalisation, Therborn implies a static understanding of 'civilisations'. They appear in his account to lack historical processes of transformation, at least after the first wave. His model allows no place for the present dynamics of civilisations. If there is a part for civilisations in globalisation, then it is as artefacts of global history that counteract homogenisation. The pace of the present is set more by globalism manifested regionally. He sidesteps civilisations as creations in the present, whether as processes (as Elias and other processual theorists would have it), as collective representations (for Durkheim) or as active ontologies (Eisenstadt). Civilisations persist residually as powerful historical presences, but do not contribute to the main energies of the world.

One further sociologist of civilisations and globalisation extends Therborn's approach, but casts civilisations as contemporary forces in global modernity. José Mauricio Domingues brings a multidimensional and nuanced account of global modernity from within contemporary critical theory. He uses the phrase 'civilisational imaginaries of contemporary modernity' to designate the counterweights that occur under the rubric of globality (2012: 98). Global modernity as a civilisation in itself emerged through the entanglement of civilisations. The expansion of global modernity coincided with the outgrowth of Western modernity (2012: 2-4). Civilisational imaginaries generate diverse forces of fragmentation in the form of various solidarities to counter the homogenising impulses of globalisation. In tension with his view that modernity has radiated from the West, Domingues follows Therborn's four paths to modernity to discern four general groupings of solidarities and agencies (2012: 21). Many of the civilisational composites trek the four paths that are changing at a striking pace since they are 'contingent, fragmented, contradictory social formations, yet they may coalesce and produce a partial fit between their dimensions' (Domingues, 2012: 22). Civilisational imaginaries are contradictory patterns, in his account, 
and therefore pace-setters. Yet they are also capable of curbing and altering global dynamics. The kinds of solidarity constructed by social actors in the conditions of global modernity - and that condition those conditions - remain startlingly varied due to the contingency of civilisational imaginaries.

The obvious conclusion from Domingues's sociology of modernity is that globalisation has no pre-ordained outcome. Rather than a shapeless determinism, globality is subject to fluctuations and tensions, as are the countervailing civilisational imaginaries of modernity. His perspective is pliable to the problematic of regionalisation also discussed by Robertson and Therborn. Although regionalisation is claimed for the domain of globalisation studies, contemporary civilisational analysis has also been able to fashion regionalisation as its own subject matter. Do findings in the two fields intersect at all? Spohn observes that contemporary civilisational analysis already incorporates regions in its analyses of cultural and institutional power at a civilisational level between national societies, inter-state relations and the emerging global arena (Spohn, 2014: 135). Arnason backs a flexible and two-sided approach. According to Arnason, historical scholarship calls for an interactive image of relationships between region and civilisation whereby the two transform each other in concrete cases (Arnason, 2003: 314-22). The state of regional studies is such that some political scientists and international relations scholars have started to look to contemporary civilisational analysis to re-problematise world regions and area studies (Katzenstein, 2010a), suggesting that more development through cross-fertilisation of propositions and empirical investigation is possible.

If there are prospects for more productive research, there is little suggestion of a convergence of views on regionalisation involving globalisation and civilisational theorists. Each paradigm handles the problematic differently. Neither is exhaustive. Globalisation theory does more to pinpoint the international mobility of institutions of power. Contemporary civilisational analysis exercises mesosociological analysis more effectively and does more at that level to illuminate constellations. There are three preconditions for further exploration of regionalisation at the interstices of both paradigms. The first is theoretical appreciation for the diversity of zones, practices, processes, actors and traditions in the twentieth century. A higher awareness of the impact of rebellions against colonialism coinciding with the breakdown of Europe's empires from the 1930s onwards is the second. Third is the weight of colonial legacies on civilisations ruled by the West. Critical reflection on contemporary civilisational analysis from the vantage point of globalisation theory stimulates attention to these three shortfalls. The global optic should prompt questions about power in the twentieth-century denouement of the colonial empires and emergence of conditions of post-coloniality. The regional optic broaches other questions about newly stimulated processes 
of pluralisation, traditionalisation and hybridisation. What new, multiple identities have emerged? How do they criss-cross class boundaries and articulate with subaltern positions? If new processes of modernisation are in train, what impact do they have on religion? The questions might be related to how some regions are more marked by the colonial past than others. The three preconditions cannot be taken further here, but could be discussion points for dialogue around regionalisation, power and civilisations.

Speculation on the future of the globalisation paradigm would be hazardous. It is striking that in sociology the main surge of interest in globalisation came in the 1990s. It has often been remarked along the way that popular globalisation discourse seems to have a good deal in common with Marxism - a significant guiding theoretical framework of capitalism for the opposition to neo-liberalism. At first sight, Marxism would appear even more at odds with contemporary civilisational analysis. Civilisational researchers are quick to dismiss the most economistic interpretations of Marxism. Yet some Marxisms resist the undertows of economism and they are relevant to civilisational analysis. If they have achieved a critical position that can have inputs into contemporary civilisational analysis, what might they contribute?

\section{Marxism and civilisational analysis}

The suggestion that Marxist histories or sociologies have a place in contemporary civilisational analysis would find few supporters in any quarter. On the civilisational side, proponents contend that Marx's economic determinism and the modernist doctrines that followed it exclude Marx's system of thought from the field. At the same time, some accept that civilisational analysis has yet to properly incorporate the economic dimension (Swedberg, 2010). Marxist critics of civilisational analysis might well contend that civilisational analysis is a new culturalism in which class conflict and power are framed out. Both sets of conclusions leave the impression that the two paradigms are mutually exclusive.

It is evident that there is no dialogue. One would be possible, however, on the basis of unorthodox interpretations of Marxist political economy that address problematics of capitalism, power and civilisations together. There are traces of interest in civilisational problematics in Marx and Gramsci's work on the symbolic and cultural dimensions of social formations. A more complete political economy of civilisational interaction in Cox's work brings Marx and Gramsci together with others in a cross-fertilisation of Marxism and civilisational analysis. The reinterpretation of Marx here privileges the imaginary of capital and money, as he presents it in The Grundrisse. Marx's 
observations on money and the capitalist imaginary amount to a sketch that is later rethought and elaborated in a sweepingly comprehensive philosophy of money by Georg Simmel (Simmel, 2004). As potent as Simmel's social theory is, the interpretation of Marx is preferred here as it connects with Marx's analysis of the subordination of labour to suggest patterns of the imaginary institution of capitalism, patterns that also involve the interaction of civilisations.

My line of thinking advances through Marx, then Gramsci and finally Cox. Marx linked money to wealth and capital, much as Simmel did later (2004), by disclosing the orders of abstraction it has brought to economic life as a component of modernity. He also drew out the cultural dimension of class struggle as well as identifying the class agency at work. Gramsci's Marxism grounds the abstraction of capitalism in a variety of social regimes that have emerged from the combat around capitalist hegemony. He emphasises the consequences of the cultural and normative dimensions of class struggle more explicitly. Both threads are mostly drawn together in Cox's model of interaction between diverse manifestations of regimes of accumulation and civilisations in the world order. To the model of civilisational analysis under construction here, Cox's interpretation of Marxism contributes an understanding of the capitalist imaginary and its highest orders of abstraction, the institution and mobilisation of power and an understanding that civilisations continue to interact with a global plane to produce variation in world capitalism.

Marx is a starting point. He had little to say about civilisation as such. Yet his deliberation on the imaginary of capitalism is suggestive of related problematics. Before exploring these problematics, Marx's main conception of civilisation as expanding and conquering capitalist modernity must be summarised, as it is the main thrust of his political economy. Capitalism, in this view, adds to the store of humanity's productive capacities while subsuming nature and non-capitalist social relations. The pre-modern relationship between polity and economy in most societies is ruptured by the cataclysmic rise of capitalist modernity. Marx argued that pre-capitalist modes of production instituted societies where state power was allied with long-distance trade in promoting economic relations. In such pre-capitalist modes of production, it was the superstructure that codetermined social relations. At the onset of capitalist modernity, capital emerges in the pre-eminent position and takes charge, as it were, of the state, thus reversing the previous balance of power. Marx forecast that the contradictions of expanding forces of production around Capital and Labour will eventually run up against the limitations of capitalist modernity. After capitalism's progressive phase of conquering nature and overcoming other modes of production and the autonomy of the state, it is plagued by its own contradictions and subject to 
cyclical downturns. Capitalism under these conditions is ready to be superseded by a higher form of society.

In parts of his work, Marx emphasises the phantasms of industrial capitalism. Passages in which the contradictions of the capitalist mode of production are stacked up against the historical character of class struggles and their consequences illuminate other aspects of capitalism. The chapter on money in The Grundrisse and chapters on the working day and the results of the immediate process of production in Capital touch on another model of the constitution of social relations (Rundell, 1987: 146-99). Marx's reconstruction of the subordination of labour to capital - the so-called subsumption model (Rundell, 1987: 17389 ) - enlarges the influence of the symbolic and normative spheres of social life in class relations, in industry and in the process of production. The struggle of classes determines not only wages and conditions but the shape of the production process, control over it and indeed the terms of engagement of industrialists and workers. However, struggle and political conflict are symbolic as well as being agential. Symbols help make sense of agency, which in turn contests the tracks of progress and alters its course, sometimes dramatically. The accumulation of capital is rendered here as a narrative in which symbolically mediated class relations have the power to shape basic institutional patterns. Capitalist industry thereby becomes an objective technological and rationalist civilisation that formally and really confronts labour in industry and endeavours to bring labour under its dominion.

Enlarging the symbolic and normative subordination of labour also puts in doubt basic premises of value and this raises important questions about the abstraction of money. The theory of money sketched in The Grundrisse is used in the current work to bolster the conceptualisation of inter-civilisational engagement in economic relations. At variance with the main perspective in Capital, Marx construes money's symbolic form as 'abstract wealth' in The Grundrisse. Money is not a representative of the forces of production, but a form that actively interposes itself in the transformation of social relations from pre-capitalist to capitalist. Money is a mobile power that passes through the world symbolising utility. In this respect, money has an elemental quality. It travels over cultures and spaces communicating its symbolisation of utility trans-spatially and trans-culturally. In doing so, it acts also as the object of different orientations to accumulation that all emerge from diverse constellations. Money is thus an abstraction to which civilisational contexts throw up different concrete orientations. As an abstraction of general purpose in the early modern outgrowth of capitalism, money was a general object of trade, finance and insurance. It follows that trade deserves a more proper place alongside the organisation of production in the theorisation of the material and symbolic outgrowth of capitalism. Marx's 
theory of money as symbolic abstraction informs the discussion of economic relations in Chapter 4.

Returning to the subsumption model of class representation, note that, as far as Marx is concerned, capitalist subsumption sets off repeated struggles for control over production and work and over regulation of other spheres of modern social life. It is possible to infer from Marx's elaboration of this model an allusion to a larger social regime of the kind that later intrigued Gramsci. Moreover, the subsumption model is given to elucidation of other kinds of power and domination. The form of domination extends to other spheres and relations between national societies and between civilisations. There is also an analogy of the subsumption of labour in the symbolic diminution of nature and the mobilisation of scientific knowledge for that purpose. By subordinating nature, capital adds to the generation of a bourgeois social world and capitalist civilisation. Marx's own words hint at the depth of this transformation. Under 'the great civilising influence of capital ... nature becomes purely an object for humankind, purely a matter of utility' (Marx, 1973: 409-10). In this rendition of the capitalist social formation, the first notion of civilisation noted above returns to the fore. However, Marx's allusions are to the symbolic and possibly imaginary dimensions of civilisation and capitalism, even though he does not pose or expressly theorise them in these terms.

In summary, there are two elements in this unorthodox interpretation of Marx that can figure in another historical narrative of the creation and expansion of capitalism. First is the mobility of money as abstract wealth. Second is the potential of class and social conflict to kindle varieties of social regulation. Both problematics may have been marginal to Marx's political economy and historical writings. They hardly translated into twentieth-century Soviet Marxism. Gramsci, on the other hand, represents a different Marxism and one with echoes in Cox's political economy. Gramsci did not consider civilisation as such, nor was the full range of Marx's critical political economy available to him. However, he is one of Marxism's most focused primary theorists on culture, economy, politics and agency and in that capacity worked up a theory of capitalism's social regimes. In 'Notes on Americanism and Fordism', he construes culture to resemble civilisation (Gramsci, 1971: 277-318). Like Georg Lukacs, he is philosophically located in a tradition of non-positivist and Romantic Marxism that is influenced by Weber (Lowy, 1996: 13-15). Given the echoes of Weber in his outlook, it is not far-fetched to suggest that there is a tacit civilisational dimension to his theory of capitalism and state formation.

Gramsci's prescient notes on Americanism are notable for two features. First, he generates significant insights into the complexity of social formations and how power is instituted in varying combinations of coercion and 
consent. Second, he explores culture and politics as constituents of variations in capitalism and, in doing so, incorporates something like a civilisational dimension; that is, a dimension of social life above culture in which elemental meanings are instituted. In the United States, a cultural and moral order aligned to Protestant capitalist hegemony had been cultivated along with the development of Fordism. Hegemony construed in this way falls somewhere between explicit and tacit power, as Castoriadis conceptualises them. Gramsci asserted that hegemony comprised several components. In the United States, the technical mechanisation of systems of production and reorganisation of the labour process appeared to demand reforms of the subjectivity and habits of life of the working class. Fordism, however, produced different versions of virtue for different classes. Hard work, acquisitiveness, sobriety, family responsibility and consumption were working-class virtues suited to largescale industry. All such virtues were promoted through moral campaigning. Moral reform became a civilising crusade to reconstruct the character of labour itself. In the United States, the promise of unprecedented ownership of leisure goods came with the constraint of new virtues in the regimentation of work. The repertoire of restraints on the 'way of life' was wide enough to include a version of virtue for the bourgeoisie as well. For the capitalists and the professional managerial elite, virtues of self-reliance and ever-energetic application were vocational forces. Patterns of ideology and culture such as these condition the structures of accumulation and regulation.

In encountering mass Americanism, European societies confronted a regime of ethics as well as an expansion of consumption. In Italy, the particular regime of accumulation and rationality associated with Americanism could not be replicated in full at that time, even though elements of Fordism were invading Italian industry in the north. While Gramsci's idea of 'civilisation' trails Marx's first notion of civilisation qua capitalist modernity, Gramsci constructs Fordism's Protestant ethics in a manner reminiscent of Weber. He identifies this as a cultural formation particular to the United States. Instead of a systemic logic that expands teleologically towards total rationalisation, the invasion of liberalism and rationality is seen as unfinished and resisted. Gramsci sheds light on the meso-sociological and micro-sociological forces competing with each other in the real-life worlds of factories, cities, families, unions and parties. The struggle against rationalisation is constant across these spheres.

Gramsci's notes also allude to the world-making, or rather remaking, that comes with Americanism as a result of the conflictual figuration of classes. In the background is modern Italy's relationship to its incomplete renaissance. Italian civilisation confronts Fordism as an entrenched world. In this confrontation, Americanism appeared to Europeans as a civilisational force of rejuvenation. 
There is thus a national struggle over the moral order that is civilisational in its contours as well as a class struggle that is political and economic.

Gramsci's reconstruction of problems of moral order and social existence in 'Americanism and Fordism' paved the way for a series of later neo-Marxist conceptions of capitalism. One neo-Gramscian offshoot turned explicitly to problematics of civilisation. Robert W. Cox has a disciplinary background in international political economy and international relations. He began by taking the implications of Gramsci's perspective on the uneven development of Italy's south beyond its national confines to an international level. For Cox to do this effectively, he harnessed theories of capitalism developed by Fernand Braudel, Karl Polanyi, Pitirim Sorokin, Georges Sorel, Harold Innis and Weber.

A plurality of versions of capitalism is implicit in both Polanyi's theorem of social economy and Gramsci's observations on the cultural composition of the American figuration. Cox's research had already laid down how various social structures of accumulation had formed in the world economy by cutting across different modes of production and class blocs. He later twisted this sense of plurality in a civilisational direction, while retaining this critical emphasis on variations to the historical structures of capitalism - a combination of problematics marginal to civilisational analysis. Cox's collection, The Political Economy of a PluralWorld, more comprehensively melds neo-Gramscian international political economy with civilisational problematics (Cox, 2002). Three of his general problematics are shared with civilisational analysis: civilisation in the singular coupled with a pluralistic notion; the nature of historical change diversified by different temporalities; and the potential of an interactive multi-civilisational order. Each is considered in turn below.

What is civilisation in Cox's estimation? There are some common-sense assumptions of civilisation and civilisations in the post-Cold War era, banal truths if you like (2002: 176-88). Cox casts civilisation in the singular as a background myth, almost as collective 'naturalized' intuition. For Cox, people do not identify with civilisation in their daily lives; it is a powerful common sense that operates at the level of the subconscious. Civilisations in the plural emerge as images built up over time as they are constructed inter-subjectively; 'civilizations exist in the mind' as a type of group animus (2002: 39). Three general orientations of the mind distinguish civilisations from one another: conceptions of time and space; how relations of individual to community are constructed; and cosmologies of the world and universe (2002: 177). Civilisations are distinguishable configurations of these three orientations.

Change is the essence of civilisations, according to Cox. Different temporalities are evidence of different rhythms of historical change. The patterns of diversity Cox finds do not match the image of territorially bound and reified entities 
that are the commonplace of neo-realism. He is led to the axiom that processes of change are the only enduring feature of civilisations. At the level of civilisation, the greatest stimuli to change come from the "carriers of interpenetrating influences' (2002: 145). It is reasonable to conclude that inter-civilisational connection counts the most, in Cox's account, in varying historical change and the settings of temporality.

This strong sense of interaction in the world order of civilisations is not confined to analysis of time and historical change. Plurality and pluralism are political values, as well as analytics. Noting US and Western hegemony in the United Nations and in world-capitalist relations, he poses his own utopia of a truly multi-civilisational international arena in which 'a weak centre in a fragmented whole' maintains a balance between states (2002: 185). Marx's image of struggling forces within societies is wholly projected by Cox into the world order as the analogy of a polycentric coexistence of civilisations without a hegemonic centre. This is the opposite of the 'one-ness' intrinsic to the project of globalisation and Anglo-American philosophies of neo-liberalism. It is premised on a substantial enlargement of mutual understanding through unconditional dialogue in which there is 'no closure, no end of history. No one (individual or civilisation) may legitimately reify the Other; i.e. treat it as an object (as in orientalism)' (2002: 174-5). Who can generate the vision for this? Cox looks to the organic intelligentsia of social movements for potential compacts of human and workers' rights, reduction of warfare and violence, remediation of threats to the biosphere and reversal of social inequalities. This is a worthy vision, though it remains unclear how polycentric norms can be instituted and communicated worldwide in an interactive politics that appears to be Cox's utopia.

Along with moves by Katzenstein and others in international relations to focus on the civilisational level (see also Unay and Senel, 2009), Cox's axiomatic comments are a significant contribution from the political sciences to the paradigm of civilisational analysis. They have not gone unnoticed and not escaped critical reception. The detractors cannot be addressed here, excepting one observation. Cox's advanced theory of international political economy is the most striking attempt to marry civilisational analysis and a version of Marxism, and none of the critics address this aspect of Cox's work.

Cox's vision of a pluri-civilisational normative global order animates the existing multipolar world, which still bears many contours of the modern empires (as he is well aware). To conclude, three comments on the historical emergence of capitalism are called for in light of the three Marxist perspectives examined in this section. First and most obvious is the accumulation and multi-nationalisation of capital. Processes of accumulation occur under different social regimes that more or less temper expansionary tendencies. The outgrowth of the economic 
sphere is a by-product of the intensification of inter-civilisational engagement in early modernity and can only properly be understood as a multidimensional process. Second, the expansion of different kinds of capitalist rationality and forms of trust are significant as cultures of capitalism. Contrary to some enthusiasts for globalisation, the expansionary pattern is not uniform, nor does it lead to uniform results. For example, practices and forms of trust are situational and should be seen as such. Arguably, trust is contingent on civilisational contexts as well. Third, the monetarisation of economic relations vividly transformed material practices and what they mean in everyday life, invoking the imaginary of money that Marx sketched in The Grundrisse. From the point of view of globalisation analysis, the financialisation of commerce, investment and accumulation represents an escalation on the global plane of economic activity. As a result, financialisation has reconstituted money as a new species of imagined wealth. Although much debated, there is a general understanding that the exponential growth of finance capital has instituted a sui generis trans-national economic power. However, from the point of view of civilisational analysis, there is a longer history to these processes that is essential to understanding the dynamic relationship of the capitalist imaginary and its civilisational varieties. These three comments are elaborated in Chapter 4 in analysis of the multidimensional engagement of civilisations.

The historical remaking of the modern world as a global world by colonial empires is tied up in this emergence of the imaginary of capitalism. Relationships of colonialism and capitalism feature in the next chapter. However, there is a third counterpoint to consider. Civilisational analysis has generated quite different perspectives from post-colonial currents on civilisations, capitalism and colonialism. Is there a juncture at which they meet?

\section{Post-colonial currents}

In this section, I compare the forming fields of post-colonial sociology and contemporary civilisational analysis to single out incongruities and demarcate points of potential dialogue. By any assessment, post-colonialism is a complex field. It is too large to survey here. The focus instead is specifically on post-colonial sociology, due to its critical meditations on both post-colonial studies and the paradigm of multiple modernities. The central barrier to finding common ground between post-colonial sociology and civilisational analysis lies with the theoretical and normative dissonances of the two fields and their criticisms of each other. From the vantage point of civilisational analysis, some outcomes over the course of post-colonialism's life 'deserve nothing but rapid dismissal, while others seem open to mutually instructive dialogue' (Arnason, 2003: x). At the same time it 
must be accepted that not all works of civilisational analysis are responsive to the potential of cross-fertilisation with other critiques of Eurocentrism. Some comments on the specific nature of post-colonial sociology are needed to clear the ground for comparison of the two fields. Potential cross-fertilisation is then explored by bringing in perspectives on connected histories.

Post-colonial sociology came from critiques of two areas of scholarship. The first target has been existing post-colonial studies, which has narrowed its power of disclosure to literary and cultural criticism (Bhambra, 2007; Boatcă and Costa, 2010). Second, there is critical alarm about sociology's general detachment from post-colonialism (Connell, 2007; Go, 2013). Apart from these common points of origin, post-colonial sociology is still solidifying. Unlike other versions of the post mode, post-colonial sociologists insist that power and epistemological domination should be central to sociology. In examination of particular histories of imperialism, post-colonial sociology has made power a central problematic in ways that have not proved possible for post-colonial studies in the humanities. But metropolitan social science is also implicated in post-imperial political, economic and structural forms of domination (Connell, 2007). By invoking a macro-sociological level of analysis of global inequalities, post-colonial sociology pinpoints the problematics of power that figure in a challenge to the epistemological foundation of metropolitan sociology. The field also claims considerable critical purchase in critiques of power at the meso-sociological and microsociological levels (Boatcă and Costa, 2010: 20-6). Post-colonial sociology thus fashions itself as a critique of the whole frame of social, economic, epistemological and political relations.

Dissensus between civilisational analysis and post-colonial sociology turns on three key issues: how culture is conceived, what politics should inform analysis, and a dispute over the character of modernity. Post-colonial critique of essentialist conceptions of civilisation pinpoints the neo-Weberian strategy of privileging European cultural dynamics. Civilisational analysis reifies cultural units, according to Boatcă and Costa (2010: 23-6). The cultural programme claimed for Europe in civilisational analysis essentialises culture, rather than making a persuasive argument for European exceptionalism (Bhambra, 2007: 5-8). In doing so, post-colonial sociologists claim, civilisational analysts bracket out power and the social with the consequence that complex landscapes of identity and conflict are homogenised. Stable cultures posited as entities fill the global picture of civilisations in a manner that resembles Huntington's analysis too much to be a viable alternative to it. Instead, post-colonial sociologists advance 'relationalism', defining this alternative as historical sociologies of those relations that manifest essences. Bhambra argues for a framework of 'connected sociologies' as an analysis of modernity as a consubstantial emergence from the relations 
between societies, particularly the hierarchies of imperialism (Bhambra, 2014). Building on connected histories, post-colonial sociology aspires to a relational framework better suited to the goals of a proper global sociology.

Contemporary civilisational analysis is not unresponsive to the critiques. Responses are most evident in process- and interaction-based approaches - the second and third approaches discussed in the second chapter. Hall and Jackson privilege process over essence in a strategic response to concerns over essentialist notions of culture (Hall and Jackson, 2007). Their emphatically 'post-essentialist' perspective is 'a serious effort to suggest and develop modes of civilisational analysis that do not rest on such misleading foundations' (2007: 2). Emphasising themes of power, process and discourse in different ways, Katzenstein's picture of civilisations posits trans-civilisational and inter-civilisational engagements as more likely than unified civilisations with a core essence. Engagements of these kinds are processes of formation and flux of regions. The processes privileged by Katzenstein are thus not essentialist reconstructions. Mention of interaction of civilisations brings Arnason to mind as the chief current-day proponent of 'intercivilisational encounters' that shape civilisations. The significance of his work is discussed in Chapter 2. For present purposes, it is mentioned to point to nonessentialist achievements in contemporary civilisational analysis. The collective research enterprises led by Hall and Jackson, Katzenstein and Arnason are all achievements beyond essentialism and should be acknowledged as such. Postcolonial sociology seems not to have taken them into account.

The second dissonance is orientation to transformative politics. Scholars in contemporary civilisational analysis do not stand out with any specific political position and so it is more accurate to describe the politics of the field as an orientation. Post-colonial sociology, by definition, is at odds with older imperial hierarchies that are reproduced in contemporary social science (Boatcă and Costa, 2010; Connell, 2007). At the same time, older post-colonial perspectives are abandoned because of their accommodation with a 'politics of image' that endorses the ethos of tolerance of existing versions of multiculturalism. In their stead, post-colonial sociology aims for a new social scientific landscape informed properly by the historical knowledge bases of the peripheries and critical disclosure of the relations of domination (Bhambra, 2014). Southern theories and sciences are foremost in this respect for their content, but also for their alternative epistemologies and methodologies (Connell, 2007). Connell does the most to empirically canvass and compare bases of knowledge of peripheries as 'Southern' ideas, beliefs and doctrines. Her quest for a science that reflects southern worlds and assists the development of a global sociology gives her a political mission that resonates with the transformative politics sought by other post-colonial sociologists. For Bhambra, by highlighting 'the importance of the politics of the present 
(and the past) in our interpretations' (2007: 147-8), post-colonial sociology can address many of the gaps in post-colonialism at large, for which the latter has been criticised from other radical perspectives. The inter-connections of the past should be reinterpreted from many standpoints and potentially with new facts in order to effect the provincialisation of Europe (Bhambra, 2007: 153-5). Any critique of the present rests on core values that should also guide interpretation of the past. Shilliam (2015) provides a solid example of practice in connected histories in his survey of decolonial scientific connections between anti-colonial movements linking Africa, New Zealand (Aotearoa), the North Pacific and the United States. The presence, contestation and activity of Maori and Pasifika communities (particularly the youth) in creating solidarities between different postcolonial cultures denies the monopoly of truth claimed by the post-colonial heirs of colonisation.

Sociology has only began to elucidate and give voice to linkages made between indigenous movements such as the Maori and Pasifika ones. Latin American scholar-activists have made more progress in highlighting the weight and political significance of alliance-building across indigenous movements. Latin American decolonial thought and praxis is one position claimed by post-colonial sociology to serve a politics of the present and to claim a point of departure from existing post-colonial critique. The findings of Latin American decolonial scholaractivists have been neglected by established post-colonial studies. Drawing on legacies of dependency theory and liberation theology, Latin American perspectives correct the loss of critical impetus evident in the one-sided cultural criticism of much of post-colonial studies (Moreno et al., 2008). Too many are silent on present-day political, social and economic conditions - a charge laid against both civilisational analysis and post-colonial thought by Marxists (Dirlik, 1997). Decolonial critique, with its deep roots in oppositional movements to which dependency theory and liberation theology are related, is oriented to projects of transformation of the relations of domination. Moreover, decolonial critique is a carrier of the specific historicity arising from a long experience of colonialism. With this strong sense of historicity, Latin American decolonial intellectuals, like post-colonial sociologists, uncouple the notion of coloniality from postmodern relativism in order to keep notions of social power and inequality at the heart of analysis. Coloniality is presented as a historical experience of power, dispossession, slavery and other modes of forced labour, and a long war of indigenous peoples and their civilisation going back to the late fifteenth century. Decolonial scholar-activists keep current-day forms of the global power of capitalism firmly in the frame. This is a strong base from which to explore indigenous civilisations, particularly in the Western hemisphere. Historical connections in the Western hemisphere that have been recently recovered have strong 
similarities to indigenous and black solidarities identified in decolonial scientific practice observed and advocated by Shilliam in the Pacific (2015). Indigenous practice is a counter-science, in Shilliam's account, due to the 'deep relation' it embodies. Shilliam observes that '[d] ecolonial science seeks to repair colonial wounds, binding back together peoples, lands, pasts, ancestors and spirits. Its greatest challenge is to bind back together the manifest and spiritual domains' (2015: 13). Forms of decolonial critique in post-colonial sociology have much to offer, but only early results are available at this point. By contrast, traditions associated with subaltern studies have not paid much attention to indigenous civilisations. Nor has contemporary civilisational analysis.

Civilisational analysis has no equivalent of a politics of present conditions. Instead the common denominator is a normative commitment to the ideals of the democratic imaginary and a critique of the totalitarianisms of the twentieth century (Eisenstadt, 1999a; Wittrock, 2000). How the social order is instituted, how conflict is shaped, how social goods are constructed and sought, and how social relations are mediated depends on deeper cultural premises and the quality of societies produced from them. Investigations into democracy are not confined to constitutions, procedures and laws but also the sources of motivation in politics. Eisenstadt poses this as the 'fragility' and continuity of modern democracy, describing it in terms of the 'central premises' of political life (1999b). Democracy is truly contingent (and hence fragile), even though informed at its roots by the cultural premises set by the political revolutions of modernity. Politics is therefore related to other dynamics of modernity in contemporary civilisational analysis, instead of acting as the pivotal point of epistemological orientation as the 'politics of the present' does for post-colonial sociology.

Eisenstadt's theses around multiple modernities are the final and most controversial area (Boatcă and Costa, 2010; Patel, 2013). Post-colonial sociologists have their own particular criticisms, best represented by Bhambra. The stated originality of Europe's cultural programme reveals a Eurocentric position too prominent for the multiple modernities paradigm to act as a thoroughgoing alternative (Bhambra, 2007: 56-74). The West is 'both the origin of modernity and ... the origin of multiple modernities' (2007: 67). Furthermore, the image of processes of multiplication of the original programme remains diffusionist. Even when finer typologies are introduced, diffusion of Western forms remains the implicit process. Despite disavowals of Orientalism, the multiple modernities paradigm amounts to a European exceptionalism unable to adequately serve pluralistic social science (Bhambra, 2007: 67-71). Bhambra's alternative is an interrogation of the very notion of modernity itself and adoption of 'connected sociologies' as a paradigm of explanation and project of change. In her project, slavery, imperialism and racism are connected to modernity (2014). Parts of 
her critique hit the mark. Even so, other aspects of civilisational analysis are bracketed out from critical assessment altogether, making it a partial critique. Bhambra treats only a fragment of Arnason's civilisational analysis and there is no acknowledgement of his variance from Eisenstadt's theses on Axial civilisations and multiple modernities. There are also other possible directions for multiple modernities that are not considered. For example, theories of power in multiple modernities carry potential for the development of an illuminating political sociology (see Knöbl, 2006a). Neither post-colonial sociology nor contemporary civilisational analysis have yet perceived that potential.

Clarification of positions on the main points of contention is a good way to start clearing the ground for common and mutual understanding on key points. The ground for dialogue can be enlarged via a reconstruction of two further positions: the use of ideal typology and the connected histories genus of global history.

Bhambra critiques ideal typology for its rigid commitment to value-relevant categories (as allegedly universal) irrespective of empirical evidence (Bhambra, 2014: 146-9). The consequence of adoption of multiple modernities as an analytic is to replicate an erroneous methodology, rather than fundamentally revising the hierarchy of knowledge and values informing it. In order to replace ideal typology, she proposes to harness the connected histories methodology pioneered by Sanjay Subrahmanyam (Bhambra, 2007: 153). For Bhambra, this paves the way for a more adequate explanatory framework. Other currents in history stress entanglement of states and civilisations by going back to an era of early modernity. For example, Shalini Randeria analyses 'uneven and entangled modernities' as a compelling reformulation of the multiple modernities paradigm incorporating diverse experiences of colonialism (2002). In the place of societies and civilisations, she emphasises intra-societal modernities in order to explore the variation in social experiences of modernity. Looking to the global plane instead, Conrad and Sachsensmaier distinguish inter-cultural connections and worldwide exchanges as articles of analysis (2007). From their point of view, some historical conjunctures are more vital in the degree of connection achieved. The fin de siècle phase of globalisation commencing in the 1880s is one such conjuncture (2007). Shilliam turns the focus to a more recent phase of building anti-colonial connectivity by looking at the deep relationality built in the 1970s and 1980s between Maori and Pasifika movements in New Zealand (Aotearoa), Black Power movements in the United States, Pan-Africanists and Rastafarians (Shilliam, 2015). Inspired by strong sentiments of solidarity and goals of consciousness-raising in overseas movements, young activists, musicians and artists found motivation to examine their own traditions and revive the modality of connection that existed in their worlds. Support for indigenous 
and black movements at the World Council of Churches in 1968 - though not so widely publicised - along with the reform programme of Vatican II Catholicism made black liberation theology a feasible and appealing way to challenge white (Pakeha) hegemony in New Zealand (Shilliam, 2015: 71-87).

Each of these perspectives on entanglements in global history displaces ideal typology. Shouldn't they get more of a hearing in civilisational analysis? The first integrationist approach seems more blocked from the results of interactive models. Ideal typology brought to much of civilisational analysis an image of civilisations as relatively detached, endogenously generated entities. By analytically isolating components of social formations for the purposes of comparison, this particular approach acts to suppress inter-relationships. In comparative analysis of a neo-Weberian inspiration, components of civilisational constellations are catalogued as types, and thus civilisations and societies appear as detached, bounded and unaffected by exogenous influences and flows. As a result, the full vitality of connections within which civilisations 'exist' and become meaningful has not been as fully recognised. Fitting civilisations to ensembles of types of components - rather than setting them against the historical background of their situated contexts and connections - inhibits a fuller picture of the abundant plurality of the social historical world including forms of domination, exploitation and violence. The emphasis on linkages that is foregrounded in connected and relational histories restores to analysis of civilisations macro-regional and meso-regional contexts and the exogenous influences on civilisations circulating in them.

An instance of the displacement of ideal types is with the presumed unity of Europe itself based on a selection of perspectives. Potential exists for paradigmatic common ground here around which adversarial dialogue could be conducted. Dipesh Chakrabarty's project of provincialisation is a helpful junction as, like post-colonial sociology, it represents greater distance from post-structuralist perspectives. His interpretive strategy undermines the image of Europe as the centre and its history as a generalisable universe (Chakrabarty, 2000). Arnason has an interesting angle on this (2003: 346-50). A realignment of Chakrabarty's project and civilisational analysis could bring strengths from each area to a newly constituted perspective. For Arnason, Chakrabarty's assertion that the figurative unity of the West should be differentiated from historical geographies of power in Europe implies a distinction between Europe's universalised provincial histories and its own outposts. The dismemberment of the figurative image of 'Europe' is a shared interest of post-colonial thought and recent civilisational perspectives alike. He points out that Eastern and Central European histories would look different with a nuanced geography of Europe's centres and peripheries. Research incorporating the multi-civilisational European past would 
respond to Chakrabarty's appeal. Some post-colonial sociologists have notably pursued a similar critical decentring of the presumed European bloc. In all, then, Chakrabarty's provincialising approach can clearly be related to the connected histories of world regions by problematising world regions whose homogeneity is exaggerated.

Subrahmanyam's connected histories could contribute to opening the intersection of the two fields. The approach brings together areas of histories artificially kept apart by the conventions and prejudices of national histories. Post-colonial sociologists have enthusiastically endorsed his methodology, if not always his findings. Comparative and historical sociologists would benefit from returning to his work for more careful consideration. His notion of 'connected histories' and his characterisation of early modernity as a conjuncture of processes embody one periodisation of early modernity running from the fourteenth to the eighteenth centuries (Subrahmanyam, 1997, 2005b). Changed material conditions in the sixteenth century furnished favourable circumstances for enlargement of the geographical reach of world connections (2005b: 107-10). Simultaneously, those conditions supported the emergence of early modernity as a global conjuncture of quite uneven and dissimilar processes - including the conjoining of major trading networks, the European voyages of exploration, conquest and colonisation, and the multivalent activities of Indian traders in the wider Asian sphere. In his prolegomenon, Subrahmanyam picked out five key vectors of integration: increased travel and growing inter-cultural awareness; greater conflict between urban and agrarian cultures and nomadic societies; a distinct outgrowth of world trade; renewed ideologies of a Universal Empire across different polities; and the coalescence in variable guises of nascent processes of individuation (1997: 736-40). Early modernity was a global conjuncture that should be 'delinked' from specifically European paths and re-scoped as a wider unity. Subrahmanyam draws out the networks traversing many regions and sometimes distant trajectories and formations. His argument discerns specific connections between and within empires and states across a Eurasian modernity.

On the surface, there seem to be good reasons for scholars from both fields to be interested in Subrahmanyam's reconstruction of the early modern conjuncture given his analysis of concurrent connected processes. His specific factors are still up for debate, of course. But the methodology should be appealing, and it clearly is for post-colonial sociologists. For Sheldon Pollock, the methodology is provisional, and is treated as such in his wide-ranging histories on Eurasian transformation. His histories illustrate barely examined disparities in early modern inter-regional and trans-regional processes (Pollock, 1998, 2004). Part of the reason for the neglect that he highlights is that the historical evidence pointing to macro-regional spheres is patchy. But the problem is more 
than an epistemological one of finding evidence. The challenge is to transcend the legacy of Orientalism with methodological shifts. In Pollock's eyes, 'connected histories' is a mode-in-the-making, capable of sorely needed scholarly work on neglected regions in neglected phases (Pollock, 1998: 6). His version incorporates the capacity to privilege processes that reach across many societies, notably the vernacularisation of Sanskrit and Latin in the early second millennium. In Pollock's hands, culture shapes the kinds of power that ruling classes develop and exercise. His historical sociology extends Subrahmanyam's scope of connected histories into language, court cultures and power.

While Pollock's research sits in civilisational analysis, Subrahmanyam's histories do not receive the recognition in the field that they should, with a few exceptions. Subrahmanyam is suspicious of the proposition that civilisations are long-term formations, and he responds with emphasis on connected regions and regional contexts. When it comes to comparative sociology's neo-Weberian meta-theoretical framework, Subrahmanyam is clearly distant. He spurns Weber's 'cultural explanation' because of its Eurocentrism and it finds no favour with him due to the privilege it accords to Western Europe (1997: 760). This may be the reason for the limited engagement of Subrahmanyam and contemporary civilisational analysis.

The reception from post-colonial sociologists is warmer. The affinity of the two makes sense at first, as Subrahmanyam's methodology decentres European exceptionalism. Subrahmanyam himself makes no comment on post-colonial sociology that I know of. But he is scathing in his critique of post-colonial currents in general. He spurns post-colonial critique in its entirety, noting the paradox that post-colonialists miss the sixteenth-century juncture in which efforts at writing world history started to emerge because of their preoccupation with the European monopoly of history (Subrahmanyam, 2005a). His hostility explains his neglect of the decolonial tradition in his histories of the Iberian empires. As observed above, Latin American post-colonial thinkers have distinguished themselves by arguing that modernity should be reconceived as a figuration of coloniality derived from the imperial formations considered here by Subrahmanyam. Extraordinarily, Subrahmanyam overlooks the work of decolonial scholars. Of course, it is the ahistorical character of post-structuralist versions of postcolonialism he has in mind.

Other world histories that have affinities with 'connected histories' show that the trend is wider. Relational histories highlighted by Randeria and Conrad, along with global history more generally, seek renewal beyond nationalist historiography. Other arguments for renewal have taken place during the time that Subrahmanyam and Pollock have been active scholars of inter-regional linkages. The problematics of connection and regionalism can be common ground 
between contemporary civilisational analysis and the connected histories advocated by post-colonial sociologists and practised by Subrahmanyam and Pollock and others. Civilisational research into world regions lays claim to a decentring effect as a result of the critique of area studies and re-problematisation of modernity that puts regions into question (Arjomand, 2014a; Katzenstein, 2010a). But there are limits too set by the multiple modernities paradigm, which could unwittingly reproduce aspects of area studies. Regional zones and civilisations might easily be conflated. The counter-argument is that regionalisation and inter-civilisational engagement are associated but variable processes. Two contrasting seventeenth-century examples serve to illustrate the point. East Asia in early modernity had a thick regional nexus engaging Japan with China, which at that time had reached a new low. Japan's response was a deliberate strategy of withdrawal. Regionalism in early modernity was defined in East Asia by this unusual pattern of engagement whereby Japan voluntarily put a distance between itself and China. By contrast, in the colonisation of Meso-American worlds the Central Americas were forcibly incorporated into a newly emergent sphere of trade, slavery and exchange. In the context of a hemisphere of inter-civilisational engagement, the Conquest related Central America to multi-layered regions and sub-regions, intra-hemispheric connections and long chains of inter-continental dependence. In these two examples, one finds very different patterns of regionalism and varying interactive environments. Japan undertook voluntary reconstruction of regionality; Central America was forcibly and violently and violent insertion into the world nexus of empires.

Both examples foreground early modernities. In existing civilisational analysis, connectedness is more adequately thrown into relief in studies of early modernity than it is in studies of later multiple modernities. A focus on early modernity as a period has brought into question accepted wisdoms about the sources of modernity. In Subrahmanyam's words, 'it is certainly important to distinguish between "colonial modernity" and that which existed both before and elsewhere, but we cannot simply assume from this that what was there before was not itself a form of modernity' (2005a: 3-4). He suggests that turning the lens of connections on longer histories of contemporary constellations can be helpful in disclosing non-Western modernities, as well as better understanding the colonial empires and the colonialities that they engendered.

\section{Conclusion}

With some interpretive licence, I have explored three paradigms in this chapter, looking for prospective relationships with the field of contemporary civilisational 
analysis. The intersections that come into view are of different kinds, and they have different prospects for progress. Civilisational analysis is close to perspectives on globalisation and regionalisation. The most illuminating of perspectives in globalisation theory examine longer historical trajectories, much as scholars of civilisations do. The claim of an intersection is more challenging to sustain with Marxism. However, the argumentation here serves to underline traces of Marx's insight into the symbolic and imaginary dimensions of capitalism. To this we can add Gramsci's elaboration of normative spheres of social life associated with different figurations of capitalism. We then have some basis for theorising how civilisations interact with global capitalist impulses to produce varying social regimes. Cox's model of international relations results from a wide-ranging synthesis of civilisational theory and neo-Gramscian Marxism. This is not the only one possible of course, but it is suggestive of much that is left out of other versions of contemporary analysis of civilisations. For Cox, civilisations are interactive and it is in a wide range of interactions that the boundaries are reset. Change comes about through a combination of endogenous contradictions and through encounters with other civilisations. Cox's accent is unmistakably on the multiplicity of civilisations formed in unintended interaction. Likewise, the capitalist imaginary produces varieties of capitalism through interaction with the multiplicity of civilisations. On the basis of Cox's theory, a key claim can be made around inter-civilisational engagement: early modernities are more important in the long formation of capitalism, particularly in respect of the cultures and juridical instruments of trust and the coalescence of the imaginary of money. This claim is explored further in the next chapter.

In the last section, the developing critique of post-colonial sociologists highlights questionable theoretical premises and methodological choices in the multiple modernities scholarship. They contend that connected histories and other versions of relational history are better equipped to provide understanding of the hierarchies of power in imperialism and in successive post-colonial formations. Empires are a formidable feature of the history of state power in modernity, and yet are only accounted for in recent decades and even then incompletely so. Post-colonial sociology invokes the centrality of empires, slavery and modern colonialism in the formation of the world system. A space can be elucidated in which the two paradigms claiming the mantle of anti-Eurocentrism could cross. For the version of civilisational analysis advocated here, I take away the potential of methodologies of relational history to also suggest connections between civilisations. Against the backdrop of other versions outlined in previous chapters and the critical counterpoints of this chapter, the next step is to elucidate the nature of inter-civilisational engagement in detail. 